South Asian J. Food Technol. Environ., 5(1): 763-770 (2019)

ISSN 2394-5168(Print), 2454- 6445(online)

www.sweft.in

\title{
Evaluation of the quality of a beverage prepared from toasted melon seeds
}

\section{Peter Isah Akubor* and Blessing Chidi Obasi}

Department of Food Science and Technology, Federal University Wukari, Taraba State, Nigeria

*Email: akuborpeter@gmail.com

\begin{abstract}
The study assessed the quality of beverage prepared from toasted melon (Colocynthis citrullus) seeds. The melon seeds were toasted at $120^{\circ} \mathrm{C}$ for $10 \mathrm{~min}$, dehulled manually, blended with hot water at 1:6 (kernel: water) ratio and the slurry was screened through a double folded cheese cloth. The extract was ameliorated with 5\% (w/v) sucrose and then flavored with pineapple, vanilla, lemon, orange, banana and mango flavors. The chemical composition and sensory properties of the beverages were determined. The toasted melon beverage containing pineapple flavor was preferred to the other beverages. The toasted melon beverage containing $0.8 \%$ pineapple flavor had $3.0 \%$ protein, $4.0 \%$ fat, $2.0 \%$ ash, $5.0 \%$ carbohydrate, $8.3^{\circ}$ Brix soluble solids and $\mathrm{pH}$ of 5.2. The non-flavored beverage was fairly acceptable. However, flavoring significantly $(\mathrm{P}<0.05)$ improved the sensory properties of the toasted melon beverage.
\end{abstract}

Keywords: Melon Seed, Beverage, Toasting, Flavoring, Acceptability.

Paper cited: Akubor, P.I. and Obasi, B.C. (2019). Evaluation of the quality of a beverage prepared from toasted melon seeds. South Asian Journal of Food Technology and Environment, 5(1): 763-770.

\section{Introduction}

In Nigeria, most of the beverages are imported and sold at prohibitive prices. This has caused a great percentage of the population to desire traditional beverages. To satisfy this group, it is necessary to upgrade the processing techniques for the production of traditional beverages. The examples of the traditional beverages that have received attention include kunun zaki, kunun-Gyada, fura, soy-kunun-zaki, apula, obiolor, zobo, soy-coconut-beverages among others. Kunun-zaki is millet or sorghum based (Adeyemi and Umar, 1994; Inatimi and Gaffar, 2004) while Kunun-gyada is produced mainly from groundnut (Sopade and Kasimu, 1992). Soy Kunun-Zaki is produced from millet flour fortified with soybean (Badifu et al., 1998). These beverages are popular in the middle belt and Northern Nigeria (Onuorah et al., 2005). Obiolor on the other hand, is a traditional non- alcoholic beverage brewed by the Igala people of Kogi State in Nigeria. Obiolor is prepared from malted sorghum, millet or maize grain depending on the locality (Achi,
1990). Fura is a semi-solid dumpling cerealbased meal prepared principally from millet though; other grains such as sorghum or their combination could be used (Iyang and Zakari, 2008; Onuh and Isah, 2009). The consumption of these beverages is gaining wider acceptance in Nigeria for relaxation and entertainment of visitors (Ukwuru et al., 2008). A similar beverage is prepared from melon seeds. Among the Ibos, melon seeds are toasted, dehulled, ground, reconstituted in water and consumed to quench thirst. The drink is regarded among the Ibos as after meal drink or refreshing dink during the dry season. Such drink is believed by the Ibos to improve the physical and mental well-being (Akobundu et al., 1982). Melon seeds are also milled and used to prepare egusi soup for their thickening capacity. Melon seeds could also be milled, mixed with pepper, salt, crayfish and other ingredients. These are molded into balls, cooked and dried over fire to produce cake known among the Ibibio of Nigeria as mbam or ikpan. Akubor (1998) reported the properties of milk prepared from melon seeds and showed that melon seed milk was not generally accepted by the consumers due to 
melon flavor of the milk. The melon seed milk contained $3.0 \%$ protein, $4.0 \%$ fat and $2.5 \%$ carbohydrate (Akubor, 1998). However, Akubor and Ogbadu (2003) evaluated the effects of processing methods on the quality and acceptability of melon seed milk and reported that toasting and germination of melon seeds improved the physicochemical and sensory properties of melon seed milk. Melon seed is good candidate for the preparation of a beverage. Previous reports showed that melon seeds contain $50 \%$ fat, $28.4 \%$ protein, $2.7 \%$ crude fiber, $3.6 \%$ ash and $8.2 \%$ carbohydrate (Akubor, 2004; Udeiden and Enwere, 2012). The seeds are rich in arginine, tryptophan, methionine, vitamins $B_{1}, B_{2}$ and minerals such as calcium, magnesium, potassium, iron and zinc (Akobundu et al., 1982; Akubor, 2004). That melon seed is a potential source of calcium and niacin is encouraging to low milk consuming countries like Nigeria, where melon seed cultivation is wide spread.

Toasting which is traditionally used to process melon seeds into a drink is known to influence the physical, chemical and functional properties of crops (Onimawo and Akubor, 2012). Toasting promotes thermal degradation of chemical components of food materials (Onimawo and Akubor, 2012). Toasting is generally accompanied with caramelization of sugar polysaccharides and maillard reactions of reducing sugars and protein of the food materials (Olapade and Akinoso, 2012). Toasting generates characteristic flavor and color which consumers require for food acceptance. The appearance, volatile acids, non-volatile acids, oils, protein and carbohydrate contents of toasted crops depend on the toasting conditions (Olapade and Akinoso, 2012). These parameters are important to the production of the end product from melon seeds. Optimum toasting condition is a function of use, type of process employed, moisture content, size and shape, wholesomeness, botanical variety and maturity of seeds (Olapade and Akinoso, 2012). The preparation of melon seed beverage in areas where it is consumed is still basically a family art that is passed on from generation to generation. The production techniques vary from house to house which results in non-uniform product. No detail information is available on the preparation and characteristics of beverage prepared from toasted melon seeds.

Addition of flavoring agents may mask the melon flavor of toasted melon seed beverage and enhance the acceptability of the beverage. There is need to determine which flavors are acceptable for a particular product type. There has been little published data on attempts to profile the types of flavoring agent that might be appropriate for different new food products in Nigerian markets (Ukwuru et al., 2008). Such information may be crucial in avoiding trial and error-based product development. The objectives of this study were to prepare a beverage from toasted melon seeds and to determine the quality of the beverage.

\section{Materials and Methods}

Preparation of melon beverage: Melon (Colocynthis citrullus) seeds were purchased from a local market in Idah Township, Kogi State, Nigeria and stored in jute bag on the laboratory bench prior to use. The seeds were cleaned of extraneous materials, toasted in a clean aluminum pan at $120^{\circ} \mathrm{C}$ for $5-30 \mathrm{~min}$. with constant stirring to brown coloration, dehulled manually and winnowed. Based on sensory evaluation, the beverage prepared from melon seeds that were toasted at $120^{\circ} \mathrm{C}$ for $10 \mathrm{~min}$ was preferred and used for further studies. By sensory evaluation as described later, the optimal kernel/water ratio for acceptable beverage was determined. Consequently, the ratio 1:6 was used for the production of the beverage. Thus the toasted melon kernels were blended with hot tap water $\left(100^{\circ} \mathrm{C}\right)(1: 6$, kernel/water) in a Kenwood blender (Model 49074, England) operated at full speed (1200 $\mathrm{rpm}$ ) for $10 \mathrm{~min}$. The resulting slurry was filtered through a double folded cheese cloth. Sucrose at 5\% (w/v) (based on sensory analysis, Table 2) was added to the beverage and thereafter, boiled at $100^{\circ} \mathrm{C}$ for $10 \mathrm{~min}$ in an aluminum pot with a lid. The beverage was hot filled into sterile bottles ( $1 \mathrm{~cm}$ head-space) and pasteurized $\left(65^{\circ} \mathrm{C}, 25 \mathrm{~min}\right)$ in a water bath. 
In a separate study, synthetic flavoring agents namely pineapple, vanilla, mango, banana and lemon at $0.7 \%(\mathrm{w} / \mathrm{v})$ (arbitrarily chosen), respectively was added to the beverage and homogenized using a homogenizer. The beverage containing pineapple flavor was selected based on sensory evaluation and used for further study. The concentration of the pineapple essence in the beverages was then varied from $0.2-1.0 \%(\mathrm{w} / \mathrm{v})$ and the beverages were assessed for the quality attributes.

Sensory evaluation of beverages: A panel of twenty trained judges randomly selected from staff and students of the Federal polytechnic, Idah community was used for the sensory evaluation. The judges were familiarized with the toasted melon beverage and the sensory attributes to be evaluated. The judges evaluated the various beverages for color, taste, flavor and overall acceptability on a 6 - point scale $(6=$ excellent, $5=$ very good, $4=$ good, $3=$ moderately good, $2=$ poor, $1=$ very poor) as described by 1 hekoronye and Ngoddy (1985). The samples $(300 \mathrm{ml}$ each) were provided in transparent glass tumblers which were 3-digit coded. The samples were randomly presented to the judges in a fluorescent- lit sensory evaluation laboratory at $10.00 \mathrm{am}$ in the mid-morning. The panelists were instructed to rinse their mouths with sachet water in between the evaluations. The order of presentation of the samples to the panelists was randomized.

\section{Determination of chemical composition:} Moisture was determined by hot air-oven drying at $105^{\circ} \mathrm{C}$ to a constant weight (AOAC, 2012). The fat content was determined by solvent extraction using Soxhlet apparatus (AOAC, 2012). The protein content was determined using the Kjeldahl method (Protein=N x 6.25 (conversion factor) (AOAC, 2012). The ash and crude fiber contents were determined by the AOAC (2012) methods. The carbohydrate content was calculated by difference [100- $(\%$ Protein $+\%$ Ash $+\%$ Fat $+\%$ Moisture $+\%$ Crude fiber)]. The soluble solids was determined with Abbe refractometer (RG 7o1, Officine Gallieler, Italy) and the result expressed in ${ }^{\circ}$ Brix. The titratable acidity (\% Lactic acid) was determined by titrating the beverage sample (10 $\mathrm{ml}$ ) against $0.1 \mathrm{~m} \mathrm{NaOH}$ to the phenolphthalein end-point. The $\mathrm{pH}$ was measured with a digital $\mathrm{pH}$ meter (Milano, Italy) at $30 \pm 2^{\circ} \mathrm{C}$. Specific gravity was determined by the specific gravity bottle methodas described by the AOAC (2012). Ascorbic acid was determined using 2, 6dichlorophenol-indophenol in a titrimetric technique (AOAC, 2012). The experiments were carried out in 3 replications in completely randomized design.

Evaluation of the microbiological quality: The total plate counts, yeast and mold counts and coliform counts were determined as described in the compendium of methods for the microbiological examination of foods (APHA, 1992). The total plate count agar plates were incubated at $35^{\circ} \mathrm{C}$ for $48 \mathrm{~h}$. The coliform bacteria were enumerated on lauryl sulphide Tryptone broth agar and incubated at $37^{\circ} \mathrm{C}$ for 24-48 $\mathrm{h}$. The yeast and molds were enumerated on potato dextrose agar. Buffered peptone water was used to homogenize the sample and incubated at $37^{\circ} \mathrm{C}$ for $18-24 \mathrm{~h}$.

Statistical analysis: The data were analyzed by analysis of variance using Statistical Package for Social Sciences (SPSS) version 20, 2007 software. Means where significantly different were separated by the least significant difference (LSD) test. Significance was accepted at $\mathrm{p}<0.05$.

\section{Results and Discussion}

Preliminary studies: The mean scores for the sensory attributes of the beverages were affected by the kernel/water ratio (Table 1). The 1:6 and 1:7 (kernel: water) dilutions had higher scores for all the attributes relative to the other dilutions. There were difficulties of mixing and/or filtration at above and below these ratios. Indeed, panelists' preferences declined sharply for those beverages that were too diluted (below 1:6 dilutions) or concentrated (above 1:7 dilutions). The choice of double-folded cheese cloth for filtration of the beverage left a high proportion of valuable residue, which could be used in the preparation of confectioneries. 
The addition of various levels of sucrose which ranged from $1-10 \%(\mathrm{w} / \mathrm{v})$ to the melon beverages resulted in significant taste differences $(\mathrm{p}<0.05)$ (Table 2). Sucrose added at $5 \%(\mathrm{w} / \mathrm{v})$ gave the most preferred taste to the beverage. The $5 \%$ level of sucrose incorporation was contrary to the report that group responses for sweetened beverages showed a sharp defined optimum point at approximately $10 \%(\mathrm{w} / \mathrm{v})$ sucrose (Drewnowski et al., 1998).

Sensory properties of toasted melon beverages: The sensory mean scores of the non-flavored and flavored melon beverages are shown in Table 3. Among the beverages, those flavored with pineapple and banana flavors had the highest scores $(p<0.05)$ for all the sensory quality attributes evaluated. It implied that either of the two flavoring agents would be suitable for the production of toasted melon beverage. However, Table 4 shows that incorporation of $0.8 \%$ (w/v) pineapple essence gave the most acceptable beverage based on higher scores for the sensory quality attributes. The sensory scores of the beverage decreased significantly $(p<0.0)$ above the $0.8 \%$ level of pineapple essence addition. The toasting process employed gave the beverage light brownish color, probably due to Maillard type reactions and degradation of the ascorbic acid component (Akubor and Ogbadu, 2003). Volatile substances that imparted flavors to the melon beverage were probably formed due to Maillard reactions between reducing sugars and amino acids as well as starch dextrinization and sugar caramelization following the toasting of the melon seeds (Olapade et al., 2012). The toasting of melon seeds and the added flavoring agents appeared to have masked the strong melon flavor of the untreated melon beverage.

Chemical composition of toasted melon beverages: The chemical composition of the raw melon seed, toasted melon kernel and the pineapple flavored melon beverage is shown in Table 5. The composition of melon seed in the present study was in agreement with the previous reports (Akubor, 1998 \& 2004). The toasting process apparently increased the crude fiber and ash contents due to moisture loss but decreased the carbohydrate and fat contents of the melon seed probably due to thermal degradation of some components. Expectedly, the various components of the beverage decreased following the dilution of the seeds. The pineapple essence used in flavoring the beverage contained $1.85 \mathrm{mg} / 100 \mathrm{~g}$ vitamin $\mathrm{C}$, $0.05 \%$ titratable acidity, 0.94 specific gravity and $\mathrm{pH}$ of 5.7 (Akubor, 1998). The addition of the pineapple essence affected the composition of the melon seed beverage, though not significantly $(\mathrm{p}>0.05)$ at the $0.8 \% \quad(\mathrm{w} / \mathrm{v})$ concentration employed.

The chemical composition of the melon beverage was comparable to those of Kununzaki and Kunun-gyada reported previously by Adeyemi and Umar (1994) except for the fat contents which were $4.0 \%$ for the toasted melon seed beverage and 1.0 and $8.0 \%$ for kunun-zaki and kunu-gyda, respectively (Sopade, 1992; Sopade and Kasmu, 1992). However, beverages with low fat content are less susceptible to rancidity. The low crude fiber content of $0.05 \%$ makes the toasted melon beverage a digestible food for children. The titratable acidity $(0.03 \%)$ and $\mathrm{pH}$ (5.2) of the melon seed beverage were similar to those reported for melon milk (Akubor, 1998) where these values were documented to enhance the stability of soymilk (Akubor and Ogbadu, 2003). However, the high moisture (86\%), high $\mathrm{pH}(5.2)$ and low acidity $(0.03 \%)$ of the toasted melon beverage would create favorable conditions for many organisms to sporulate and multiply (Umoh, 2003). This could reduce the shelf life of the beverage unless it is treated with chemical preservatives such as citric acid (Akubor et al., 2002; Osuntoogun and Abaoba, 2004). The vitamin $C$ content of the melon beverage $(0.46 \mathrm{mg} / 100 \mathrm{~g})$ showed that melon seed is a poor source of the vitamin (Onuora and King, 1983; Udeiden and Enwere, 2012). However, fruit juices such on orange, guava, pineapple among others that are good sources of vitamin $\mathrm{C}$ could be incorporated to improve the vitamin $\mathrm{C}$ level of the beverage.

Microbiological quality of toasted melon beverage: The microbiological quality of the toasted melon beverage is presented in Table 6 . The toasted melon beverage did contain yeasts, molds and coliform bacteria. The total plate 
Evaluation of the quality of a beverage prepared from toasted melon seeds

count of microorganisms in the toasted melon beverage was $5 \times 10^{2} \mathrm{cfu} / \mathrm{ml}$. The level of microorganisms in the beverage was low when compared to $2.5 \times 10^{4}$ to $5.3 \times 10^{4}$ reported for Horchata De chuffs (Mosquera et al., 1996). This indicates satisfactory handling of the beverage during the production. Yeasts, molds and coliform bacteria were not detected in the toasted melon beverage. The presence of coliform bacteria in food is undesirable because it is an indication of poor hygienic or inadequate processing (especially heat treatment) and post process contamination of foods (Frazier and

Table 1: Mean sensory scores of toasted melon beverage as affected by seed to water dilution

\begin{tabular}{|c|c|c|c|c|}
\hline Seed: Water & Color & $\begin{array}{c}\text { Sensory attributes } \\
\text { Taste }\end{array}$ & Flavor & $\begin{array}{c}\text { Overall } \\
\text { acceptability }\end{array}$ \\
\hline $1: 4$ & $2.2^{\mathrm{b}}$ & $3.1^{\mathrm{b}}$ & $2.3^{\mathrm{c}}$ & $2.4^{\mathrm{d}}$ \\
$1: 5$ & $2.9^{\mathrm{a}}$ & $3.6^{\mathrm{a}}$ & $2.9^{\mathrm{c}}$ & $2.2^{\mathrm{d}}$ \\
$1: 6$ & $3.3^{\mathrm{a}}$ & $3.5^{\mathrm{a}}$ & $3.9^{\mathrm{a}}$ & $3.5^{\mathrm{a}}$ \\
$1: 7$ & $3.8^{\mathrm{a}}$ & $3.4^{\mathrm{ab}}$ & $3.3^{\mathrm{b}}$ & $3.1^{\mathrm{b}}$ \\
$1: 8$ & $3.3^{\mathrm{a}}$ & $3.2^{\mathrm{ab}}$ & $3.5^{\mathrm{a}}$ & $3.0^{\mathrm{b}}$ \\
$1: 9$ & $2.4^{\mathrm{b}}$ & $1.6_{\mathrm{c}}^{\mathrm{c}}$ & $2.4^{\mathrm{c}}$ & $2.6^{\mathrm{c}}$ \\
$1: 10$ & $1.5^{\mathrm{c}}$ & $1.1^{\mathrm{d}}$ & $2.2^{\mathrm{c}}$ & $2.1^{\mathrm{d}}$ \\
$\operatorname{LSD}_{(0.50)}$ & 0.5 & 0.4 & 0.5 & 0.3 \\
\hline
\end{tabular}

Means(n-20) within a column with the same superscript were not significantly different( $\mathrm{p}>0.05)$.

Table 2: Effect of sucrose concentration on the sensory properties of toasted melon beverage

\begin{tabular}{|l|c|c|c|c|c|c|c|c|c|c|}
\hline \multirow{2}{*}{$\begin{array}{c}\text { Sensory } \\
\text { attribute }\end{array}$} & \multicolumn{9}{|c|}{ Sucrose (\%) level } \\
\cline { 2 - 10 } & $\mathbf{0}$ & $\mathbf{1}$ & $\mathbf{3}$ & $\mathbf{4}$ & $\mathbf{5}$ & $\mathbf{6}$ & $\mathbf{7}$ & $\mathbf{8}$ & $\mathbf{9}$ & $\mathbf{1 0}$ \\
\hline Color & $4.2^{\mathrm{a}}$ & $4.2^{\mathrm{a}}$ & $4.1^{\mathrm{a}}$ & $4.0^{\mathrm{a}}$ & $4.1^{\mathrm{a}}$ & $4.0^{\mathrm{a}}$ & $4.1^{\mathrm{a}}$ & $4.0^{\mathrm{a}}$ & $4.1^{\mathrm{a}}$ & $4.0^{\mathrm{a}}$ \\
Taste & $3.9^{\mathrm{b}}$ & $4.0^{\mathrm{b}}$ & $4.4^{\mathrm{b}}$ & $4.5^{\mathrm{b}}$ & $4.8^{\mathrm{a}}$ & $4.4^{\mathrm{b}}$ & $4.2^{\mathrm{b}}$ & $4.0^{\mathrm{b}}$ & $4.4^{\mathrm{b}}$ & $3.8^{\mathrm{c}}$ \\
Flavor & $4.4^{\mathrm{b}}$ & $4.3^{\mathrm{b}}$ & $4.4^{\mathrm{b}}$ & $4.5^{\mathrm{a}}$ & $4.6^{\mathrm{a}}$ & $4.3^{\mathrm{b}}$ & $4.3^{\mathrm{b}}$ & $4.2^{\mathrm{b}}$ & $4.1^{\mathrm{b}}$ & $4.0 \mathrm{~b}$ \\
Overall & $4.2^{\mathrm{b}}$ & $4.3^{\mathrm{b}}$ & $4.5^{\mathrm{b}}$ & $4.5^{\mathrm{b}}$ & $4.7^{\mathrm{a}}$ & $4.1^{\mathrm{b}}$ & $4.0^{\mathrm{b}}$ & $4.1^{\mathrm{b}}$ & $4.0^{\mathrm{b}}$ & $4.0^{\mathrm{b}}$ \\
acceptability & & & & & & & & & & \\
\hline
\end{tabular}

Means $(\mathrm{n}=20)$ within a row with the same superscript were not significantly different $(\mathrm{p}>0.05)$.

Table 3: Effect of type of flavoring agent on the sensory properties of toasted melon beverage

\begin{tabular}{|c|c|c|c|c|}
\hline \multirow{2}{*}{$\begin{array}{c}\text { Flavoring } \\
\text { agents }\end{array}$} & \multicolumn{4}{|c|}{ Sensory attributes } \\
\hline & Color & Taste & Flavor & Overall acceptability \\
\hline Control & $4.2^{b}$ & $4.6^{\mathrm{b}}$ & $4.4^{\mathrm{b}}$ & $4.3^{b}$ \\
\hline Lemon & $1.5^{\mathrm{c}}$ & $4.5^{\mathrm{b}}$ & $1.7^{\mathrm{c}}$ & $1.2^{\mathrm{c}}$ \\
\hline Mango & $2.1^{\mathrm{c}}$ & $4.6^{\mathrm{b}}$ & $2.3^{\mathrm{c}}$ & $2.2^{\mathrm{c}}$ \\
\hline Orange & $4.2^{\mathrm{b}}$ & $4.6^{\mathrm{b}}$ & $2.4^{\mathrm{c}}$ & $4.8^{\mathrm{b}}$ \\
\hline Pineapple & $5.5^{\mathrm{a}}$ & $5.7^{\mathrm{a}}$ & $5.8^{\mathrm{a}}$ & $5.8^{\mathrm{a}}$ \\
\hline Banana & $5.6^{\mathrm{a}}$ & $5.3^{\mathrm{a}}$ & $5.5^{\mathrm{a}}$ & $5.4^{\mathrm{a}}$ \\
\hline Vanilla & $4.4^{\mathrm{b}}$ & $4.2^{\mathrm{b}}$ & $1.7^{\mathrm{c}}$ & $1.3^{\mathrm{c}}$ \\
\hline $\mathrm{LSD}_{0.05}$ & 0.9 & 0.7 & 0.6 & 0.5 \\
\hline
\end{tabular}

Beverages were evaluated on 6-point scale ( $6=$ excellent, $5=$ very good, $4=$ moderately good, $2=$ poor, $1=$ very poor). Beverages were prepared at 1:6(seed: water), $5 \%$ sucrose concentration and $0.7 \%(\mathrm{w} / \mathrm{v})$ flavoring agent concentration. Means within a column with the same superscript were not significantly different( $p>0.05)$. 
Table 4: Mean sensory scores of toasted melon beverage containing various concentrations of pineapple flavor

\begin{tabular}{|c|c|c|c|c|c|c|c|}
\hline \multirow{2}{*}{$\begin{array}{c}\text { Sensory } \\
\text { attribute }\end{array}$} & \multicolumn{7}{|c|}{ Pineapple flavor(w/v) } \\
\cline { 2 - 7 } & $\mathbf{0}$ & $\mathbf{0 . 2}$ & $\mathbf{0 . 4}$ & $\mathbf{0 . 6}$ & $\mathbf{0 . 8}$ & $\mathbf{1 . 0}$ & LSD $_{\mathbf{0 . 0 5}}$ \\
\hline Color & $4.0^{\mathrm{b}}$ & $3.7^{\mathrm{b}}$ & $4.3^{\mathrm{b}}$ & $4.7^{\mathrm{b}}$ & $5.7^{\mathrm{a}}$ & $2.2^{\mathrm{c}}$ & 0.7 \\
Taste & $4.7^{\mathrm{b}}$ & $3.6^{\mathrm{c}}$ & $4.0^{\mathrm{b}}$ & $4.7^{\mathrm{b}}$ & $5.6^{\mathrm{a}}$ & $2.3^{\mathrm{d}}$ & 0.8 \\
Flavor & $4.2^{\mathrm{b}}$ & $3.6^{\mathrm{c}}$ & $4.4^{\mathrm{b}}$ & $5.0^{\mathrm{b}}$ & $5.5^{\mathrm{a}}$ & $2.3^{\mathrm{c}}$ & 0.5 \\
Overall & $4.4^{\mathrm{b}}$ & $3.8^{\mathrm{b}}$ & $4.2^{\mathrm{b}}$ & $4.0^{\mathrm{b}}$ & $5.5^{\mathrm{a}}$ & $2.0^{\mathrm{c}}$ & 0.8 \\
acceptability & & & & & & & \\
\hline
\end{tabular}

Beverages were evaluated on 6 -point scale $(6=$ excellent, $5=$ very good, $4=$ moderately good, $2=$ poor, $1=$ very poor $)$. Beverages were prepared at 1:6(seed: water) and 5\% sucrose concentration. Means within a column with the same superscript were not significantly different $(\mathrm{p}>0.05)$.

Table 5: Chemical composition of melon seed, toasted melon seed and toasted melon Beverage

\begin{tabular}{|c|c|c|c|}
\hline Composition & Melon seed & Toasted melon seed & Toasted melon beverage \\
\hline Crude protein $(\%)$ & $20.1^{\mathrm{b}} \pm 0.8$ & $21.0^{\mathrm{a}} \pm 0.1$ & $3.0^{\mathrm{c}} \pm 0.01$ \\
\hline Crude fat $(\%)$ & $45.0^{b} \pm 0.9$ & $46.0^{\mathrm{a}} \pm 0.3$ & $4.0^{\mathrm{c}} \pm 0.2$ \\
\hline $\operatorname{Ash}(\%)$ & $3.0^{\mathrm{b}} \pm 0.4$ & $3.4^{\mathrm{a}} \pm 0.4$ & $2.0^{\mathrm{c}} \pm 0.8$ \\
\hline Crude fiber $(\%)$ & $1.80^{\mathrm{b}} \pm 0.9$ & $2.2^{\mathrm{a}} \pm 0.4$ & $0.05^{\mathrm{c}} \pm 0.9$ \\
\hline Moisture $(\%)$ & $11.0^{\mathrm{b}} \pm 0.1$ & $7.0^{\mathrm{c}} \pm 0.4$ & $86.0^{\mathrm{a}} \pm 0.2$ \\
\hline Carbohydrate(\%) & $19.1^{b} \pm 0.5$ & $20.4^{\mathrm{a}} \pm 0.3$ & $5.0^{c} \pm 0.6$ \\
\hline $\mathrm{Ph}$ & ND & ND & $5.2 \pm 0.9$ \\
\hline Soluble solids $\left({ }^{\circ}\right.$ Brix $)$ & ND & ND & $8.3 \pm 0.1$ \\
\hline $\begin{array}{l}\text { Titratable acidity }(\% \\
\text { lactic acid) }\end{array}$ & ND & ND & $0.03 \pm 0.8$ \\
\hline Specific gravity & ND & ND & $0.9719 \pm 0.3$ \\
\hline Vitamin $C(\mathrm{mg} / 100 \mathrm{~g})$ & ND & ND & $0.46 \pm 0.4$ \\
\hline
\end{tabular}

Means \pm Standard deviation (SD) of 3 replications. Beverages were prepared at 1:6(seed: water), 5\% sucrose concentration and $0.8 \%(\mathrm{w} / \mathrm{v})$ pineapple essence. Means within a row with the same superscript were not significantly different $(\mathrm{p}>0.05)$.

Table 6: Microbiological quality of beverage prepared from toasted melon seed

\begin{tabular}{|l|c|}
\hline Microbiological quality $(\mathbf{c f u} / \mathbf{m l})$ & Toasted melon beverage \\
\hline Total plate count & $5 \times 10^{2}$ \\
Yeast and mold count & Nill \\
Coliform count & Nill \\
\hline
\end{tabular}

Values are means of 3 replications.

Westhoff, 1995). Most are common environmental contaminant of foods due to their ability to produce spores. Speices of molds such as Aspergillus, Penicillium and Fusarium are known to produce deleterious mycotoxins under favorable conditions (Frazier and Westhoff, 1995). The absence of molds in the beverage indicates that the toasted beverage is safe.

\section{Conclusion}

It may be concluded that acceptable beverage was produced from toasted melon seeds. The palatability of the beverage was improved by the addition of pineapple flavor. The solids of the toasted melon beverage separate out easily and the beverage is usually shaken before consumption. Studies on improving the stability 
and rheological properties of toasted melon beverage are recommended.

\section{References}

Achi, O.K. (1990). Microbiology of obiolor: a Nigerian fermented non-alcoholic beverage. Journal of Applied Bacteriology, 69: 321-325.

Adeyemi, I.A. and Umar, S. (1994). Effect of method of manufacture on quality characteristics of Kunun-zaki: a milletbased beverage. Nigerian Food Journal, 12: $23-41$

Akobundu. E.N.T., Cherry, J.P. and Simons, J.G. (1982). Chemical, functional and nutritional qualities of egusi (Cocynthis citrullus L) seed protein products. Journal of Food Science, 35(1): 47-82.

Akubor, P.I and Ogbadu, R.L. (2003). Effects of processing methods on the qualityacceptability of melon milk. Plants food for Human Nutrition, 58: 1-6.

Akubor, P.I. (1998). Physicochemical and sensory characteristics of melon seedmilk. Journal of Food Science and Technology, 35(1): 93-97.

Akubor, P.I. (2004). Influence of processing methods on the chemical and functional properties of melon (Colocynthis citrullus) seeds. Journal of Food Science and Technology, 41(2):181-185

Akubor, P.I., Achi, O.K. and Offonry, S.U. (2002). Influence of storage on chemical, microbial and consumer acceptability of a milk -like product made from melon seeds. Plant Foods for Human Nutrition, 57: 191-196.

AOAC (2012). Official Method of Analysis. Association of Analytical Chemists, Washington, DC.

APHA (1992). In: Compendium of methods for microbiological examination of foods. Vandeszant ,C. and Splitstoesser, D.F. (Eds). American Public Health Association, Washington DC. Pp. 961 074

Badifu, G.I.O., Anuonye. J.C. and Inyang, C.U. (1998). Development and stability of spiced soy-millet flour for the preparation of Soy-kunun-zaki: A non-alcoholic beverage. Journal Applied Science and Management, 2: 93-97.

Drewnowski, A., Nordensten, K. and Dwyer, J. (1998). Replacing sugar and fatin cookies: Impact on product quality and preference. Food Analysis and Preference, 9: 13-20.

Frazier, W.C. and Westhhoff, D.C. (1995). Food microbiology. $4^{\text {th }}$ Edition. MH publisher, New Delhi. Pp 320368.

Inatimi, E. and Gaffar, E.B. (2004). Kunun-zaki: Nonalcoholic beverage prepared from sorghum grains-chemical analysis for nutrient content of fresh samples. Nigerian Journal of Biotechnology, 5: 21-23

Iyang, C.U. and Zakari, U.M. (2008). Effect of germination and fermentation of pearl millet on proximate, chemical and sensory properties of instant fura. A Nigerian cereal food. Pakistan Journal of Nutrition, 7(1): 9-12.

Mosquera, L.A., Sims, C.A., Bates, R.P. and Okeefe, S.F. (1996). Flavors and stability of Horchat De Chufas. Journal of Food Science, 61(4): 856-861.

Olapade, A.A., Akinoso, R. and Oduwaye, A.O. (2012). Changes in some physicochemical properties of Cassia sieberiana seeds during roasting. Nigerian Food Journal, 30(1): 26-34

Onimawo I.A and Akubor, P.I.(2012). Food chemistry (Integrated approach with biochemical background). 2nd edn. Joytal Printing Press, Agbowo, Ibadan, Nigeria

Onuh, J.O. and Isah, H. (2009). Production and evaluation of fura beverage made from millet supplemented with sweet potato flour. Nigerian Journal of Nutritional Science, 30(1): 25-32.

Onuora, J.O. and King, R.O. (1983). Melon seed flour: Composition and factors affecting the extractability of nitrogenous constituents. Lebensm Wiss $U$ Technology, 16: 162-166.

Onuorah, S.J., Adesiyan, A.H. and Addeyo, J.O. (2005). Survival and multiplicationof Staphylococcus aureus and Escherichia coli in a Nigeria cereal drink -Kunun- 
zaki: Effect of spices and temperature. Journal of Food Science and Agriculture, 1: 169-173.

Osuntoogun, B. and Abaoba, O.O. (2004). Microbiological and physicochemical evaluation of some non-alcoholic beverages: Pakistan Journal of Nutrition, 3(3): 188-192.

Sopade, P.A. (1992). Kunun-zaki and Kunungyada. Two traditional Nigerian beverages. Food Laboratory News, 8(1): 17-21.

Sopade. P.A. and Kasimu, A.I. (1992). Rheological characterization of Nigerian liquids and semi-liquid foods: Kununzaki and Kunun-gyada. Nigerian Food Journal, 10:23-33.
Udeiden, I.U and Enwere, N.J. (2012). Effect of substitution of melon with soybean on the nutrient content and sensory properties of traditional cakes. Nigerian Food Journal, 30(2): 95-99.

Ukwuru, M.U., Omachona, L.J and Onokah.N. (2008). Production and quality assessment of tigernut (Cyperus esculentus) imitation milk during storage. Journal of Food Science and Technology, 45: 180-182.

Umoh, U.J. (2003). Safety and quality assessment of traditionally fermented soybean and enriched millet based beverage, fura. Nigerian Food Journal, 21:62-65.

\begin{tabular}{|ll|}
\hline Received & : January, 2019 \\
Revised & : February, 2019 \\
Published & : June, 2019 \\
\hline
\end{tabular}

